\title{
Paleoenvironmental interpretation of late Quaternary molluscan assemblages from southern South America: A taphonomic comparison between the Strait of Magellan and the Beagle Channel
}

\author{
Javiera Cárdenas ${ }^{1,2}$, Sandra Gordillo ${ }^{3,4}$ \\ ${ }^{I}$ Fundación Centro de Estudios del Cuaternario (CEQUA), Av. Bulnes 01855, Punta Arenas, Chile. \\ 2 Centro de Ciencias Ambientales EULA-Chile, Universidad de Concepción, Casilla 160-C, Barrio Universitario s/n, Concepción, \\ Chile. \\ javieracardenas@udec.cl \\ ${ }_{3}^{3}$ Centro de Investigaciones en Ciencias de la Tierra, Consejo Nacional de Investigaciones Cientificas y Técnicas (CICTERRA, CO- \\ NICET), Av. Vélez Sársfield 1611, X5016GCA, 5000, Córdoba, Argentina. \\ ${ }^{4}$ Centro de Investigaciones Paleobiológicas (CIPAL), Facultad de Ciencias Exactas, Físicas y Naturales, Universidad Nacional de \\ Córdoba, Av. Vélez Sársfield 299, 5000, Córdoba, Argentina. \\ sgordillo@efn.uncoredu
}

\begin{abstract}
This study analyzes the Holocene molluscan assemblage in raised marine terraces along the coasts of the Strait of Magellan and the Beagle Channel. A total of 33 gastropods and 12 bivalves were identified. They constitute the first mollusk listing for deposits in the Strait of Magellan. Taphonomic analysis suggests a high energy environment with epifaunal elements in the Strait of Magellan and a low energy environment with the predominance of infaunal elements in the Beagle Channel. All the collected species are living taxa suggesting that postglacial climatic variations were not enough to alter the composition of the communities since at least 6,000 yr BP in the southern Chile-Argentina region.
\end{abstract}

Keywords: Late Quaternary, Mollusks, Paleoecology, Taphonomy, Strait of Magellan, Beagle Channel, Chile, Argentina.

RESUMEN. Interpretación paleoambiental de ensambles de moluscos del Cuaternario tardío del sur de América del Sur: una comparación tafonómica entre el Estrecho de Magallanes y el Canal Beagle. Este trabajo analiza los ensambles de moluscos del Holoceno de las terrazas marinas presentes a lo largo de las costas del Estrecho de Magallanes y del Canal Beagle. Un total de 33 especies de gastrópodos y 12 de bivalvos fueron identificados. Ellos constituyen un primer listado de moluscos para los depósitos del Estrecho de Magallanes. El análisis tafonómico sugiere un ambiente de alta energía con elementos epifaunales en el Estrecho de Magallanes y un ambiente de baja energía con el predominio de elementos infaunales para el Canal Beagle. Todas las especies colectadas son taxa vivientes, lo que sugiere que las variaciones climáticas postglaciales no fueron suficientes para alterar la composición de las comunidades desde al menos 6.000 años AP en el extremo austral de Chile-Argentina. 


\section{Introduction}

The southern tip of South America, Tierra del Fuego, experienced the combined effects of glaciations, changes in the sea level and interrupted connectivity between the Atlantic and the Pacific Ocean. Given that this area lies between both oceans, it is a critical region for the evaluation of paleoenvironmental changes and the interpretation of faunal distributions in the Magellan Region (Gordillo et al., 2008). Previous research in the Strait of Magellan and the Beagle Channel revealed that marine events during the Pleistocene and Holocene are represented by marine terraces with altitudinal differences resulting from glacio-isostatic effects and the neotectonic uplift which occurred after the Last Glacial Maximum (LGM) (Brambati et al., 1998; Rabassa et al., 2000).

Quaternary marine deposits containing mainly mollusks are extensively distributed along the coasts of the Strait of Magellan and the Beagle Channel (Rabassa et al., 1986; Gordillo et al., 1992; Brambati et al., 1998). Previous studies along the southern Tierra del Fuego coastline show that mollusks are a key to reconstruct Holocene paleocommunities (Gordillo, 1999) and to evaluate changes in faunal composition after the LGM (Gordillo et al., 2005). Interspecies variations existing in the fossil record are the result of a combination of life habits, intrinsic shell properties and habitat. In this way, taphonomic analyses may constitute a powerful tool for paleoenvironmental analyses of Quaternary marine deposits (Brandt, 1989; Nielsen and Funder, 2003).

The objective of this study is to compare the Holocene molluscan assemblages located along the Strait of Magellan and the Beagle Channel coastlines by means of taxonomic, paleoecologic and taphonomic analyses.

\section{Materials and Methods}

\subsection{Study area}

The coastal area examined in this study consists of 11 localities, with a total of 14 marine terraces along the Strait of Magellan and the Beagle Channel (Fig. 1, Table 1).

Strait of Magellan. The Strait of Magellan separates Patagonia from Tierra del Fuego. It was repeatedly occupied by outlet glaciers of an expanded southern Andean ice cap during successive Pleistocene glaciations (Porter et al., 1992; Kilian et al., 2007). Today, the strait is dominated by an indented rocky shoreline and characterized by semi-diurnal and heterogeneous tides with mean amplitudes ranging from $1.2 \mathrm{~m}$ on the west coast to $9 \mathrm{~m}$ in the Atlantic inlet of the east coast (Andrade, 1991).

Brambati et al. (1998) recognized four orders of marine terraces: I, II, III and IV order; with their age estimations based on radiometric dating of fossil macrofauna. The selected localities for paleontological samples correspond to five sites previously dated by Brambati et al. (1998): Bahía Porvenir (BP), Puerto del Hambre (PH), Punta Palo (PP), Punta Zeger (PZ) and Seno Otway (SO) (Table 1).

Beagle Channel. The Beagle Channel is located in the seismically active tectonic area of the Fuegian Andes and was covered during the Last Glacial Maximum. This channel is a glacial Andean valley, occupied by the sea since 8,000 yr BP (Rabassa et al., 1986). It extends for $180 \mathrm{~km}$ long in a W-E trend linking the Atlantic and Pacific oceans along the southern coast of Tierra del Fuego. The northern Beagle Channel is characterized by a Holocene terrace system with at least 3 orders of terraces at 10-8 m, 6-4 m and 3-1.5 m (Gordillo et al., 1992). Today, the Beagle Channel, is dominated by an indented, rocky shoreline, with pocket gravel beaches. Tides are semi-diurnal with mean amplitudes of one meter (e.g., $1.1 \mathrm{~m}$ at Ushuaia) (Gordillo et al., 1992). The selected study localities for paleontological samples correspond to sites previously dated (Table 1): Alakush (AK), Bahía Brown (BB, two levels), Harberton (HA), Isla Gable (IG), Lago Roca (LR) and Ushuaia (US).

\subsection{Material studied}

\subsubsection{Taxa composition and paleoecology}

Fossil mollusks were collected from selected terraces in the Strait of Magellan and the Beagle Channel. Three samples of $10 \mathrm{dm}^{3}$ bulk of sediment and biologic material were obtained from each terrace; samples were sieved in the field using $1 \mathrm{~mm}$ and $0.05 \mathrm{~mm}$ sieves to reduce volume. All specimens were sorted, counted and identified to the species level in the laboratory. Taxonomic and paleoecologic aspects of the mollusks were studied and examined. The autoecological characterization of the fossil 

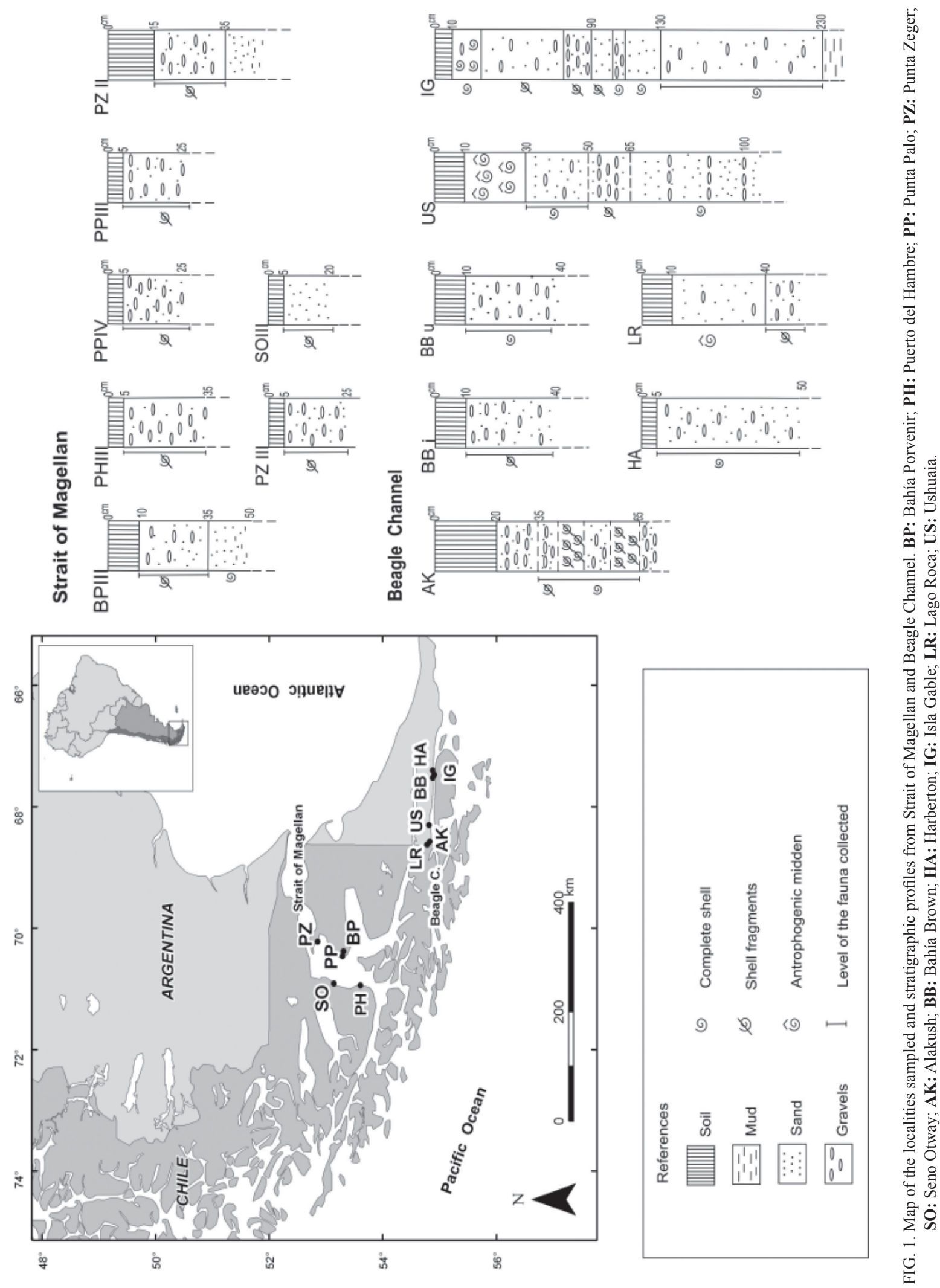


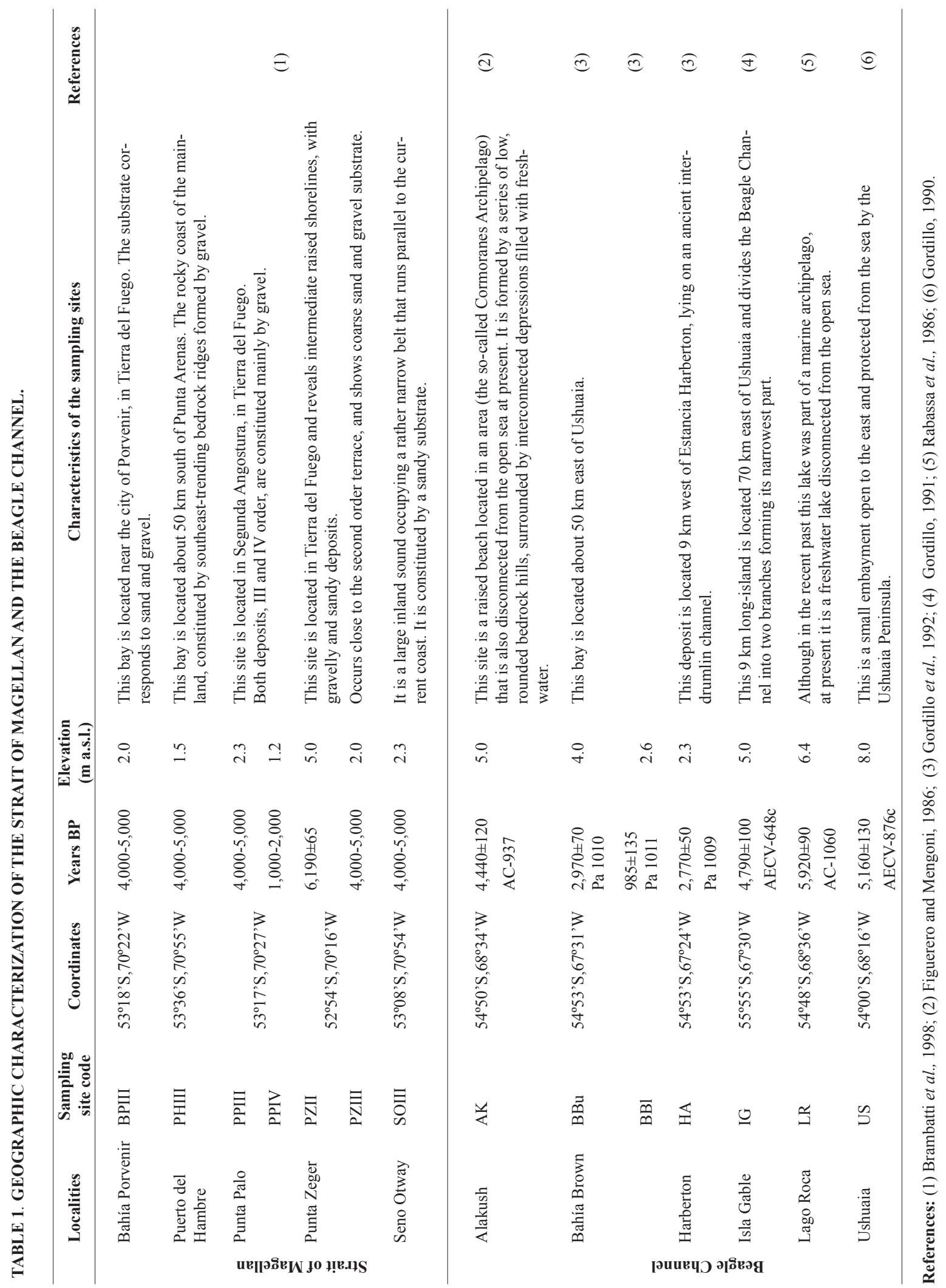


taxa and their patterns of distribution (i.e., substratum, depth and mode of life, nature of locomotion and feeding) were derived from comparison with the ecology of their current living counterparts. The identification and taxonomic status are based on Soot-Ryen (1959), Castellanos and Landoni (1988, 1993), Linse (1999), Valdovinos (1999), Reid and Osorio (2000), Osorio and Reid (2004). Specimens were deposited at the Centro de Investigaciones Paleobiológicas (CIPAL), Universidad Nacional de Córdoba, Argentina.

\subsubsection{Taphonomic analyses}

Taphons. Five filter feeder bivalve species were chosen for taphonomic analysis: Mytilus edulis chilensis (Hupé, 1854), Perumytilus purpuratus (Lamarck, 1819), Aulacomya atra (Molina, 1782), Tawera gayi (Hupé, 1854) and Retrotapes exalbidus (Dillwyn, 1817). This selection was based on the high abundance of these taxa, their ecological requirements and the distributional ranges that have been compiled and are common to both regions, thereby facilitating comparisons (Table 2).

Taphonomic attributes. Each specimen was characterized based on the main taphonomic features to reconstruct paleoenvironment conditions.

Type of valve (right, left): A significant concentration of one valve type indicates uneven hydrodynamic properties such as beaches or areas with tidal influence (Parsons and Brett, 1991).

Disarticulation of bivalves: Articulated shells are associated with rapid burial or transport capacity (Parsons and Brett, 1991).

Shell fragmentation: Breakage of skeletons is usually related to exposure to high energy environments resulting from wave action, tides or winds (Zuschin and Stanton, 2001).

Abrasion: The abrasion degree is associated to environmental energy, time of exposure and particle size of abrasive agents (Parson and Brett, 1991).

Biotic interactions: This refers to different interactions with other organisms that remain in the shell, such as encrusted shells, borings, tunnels and drill holes made by predatory gastropods (Farinati et al., 2006).

Twelve marines terraces were considered for taphonomic analyses BPIII, PHIII, PPIII, PPIV, PZII, PZIII, AK, BBu, HA, IG, LR and US. Seno Otway (SOIII) and Bahía Brown (BBl) show a low species richness and there is no record of the bivalves selected for taphonomic analyses. Therefore these sites are considered only for analyses of composition and species richness (Table 3).

\section{Results}

\subsection{Taxa composition and paleoecology}

A total of 2,727 specimens of mollusks were collected. The whole faunal content is composed of 45 mollusk species, 12 species of bivalves and 33 gastropods (Table 2).

The Magellan Strait has the highest species richness with a total of 43 species, while the deposits of the Beagle Channel have 22 species. Nineteen of the species are present in both areas: Fissurella radiosa, Nacella deurata, Nacella magellanica, Margarella violacea, Crepipatella dilatata, Calyptrea pileolus, Trophon geversianus, Xymenopsis muriciformis, Acanthina monodon, Pareuthria plumbea, Siphonaria lessoni, Aulacomya atra, Mytilus edulis chilensis, Perumytilus purpuratus, Mulinia edulis, Prothotaca antiqua, Retrotapes exalbidus, Tawera gayi and Hiatella solida (Table 2, Figure 2A). The sites with the greatest diversity are PHIII and PZIII, with 29 and 23 species respectively in the Strait of Magellan, and in the Beagle Channel the greater richness occurs in LR, with 16 species and HA with 14 (Figure 2B).

Of the 2,133 specimens collected in the Strait of Magellan, 70\% are gastropods; while in the Beagle Channel, $68 \%$ of the 594 specimens are bivalves. Organisms from the intertidal and subtidal zones are dominant in both areas. Hard substrate and epybissate species dominate in the Strait of Magellan, while the Beagle Channel is dominated by species showing preference for soft substrate and an infaunal mode of life (Table 2). Many gastropods are phytophagous $(60 \%)$, followed by carnivores $(36 \%)$ with a minor proportion of filter feeders whereas all bivalves studied are filter feeders (Table 2).

\subsection{Taphonomic analysis}

Strait of Magellan terraces. Marine terraces located in this area are mainly composed of epifaunal elements, characterized by poorly preserved shell remains. There is a difference in the left/right proportion of valves in all sites, which suggests transport. 


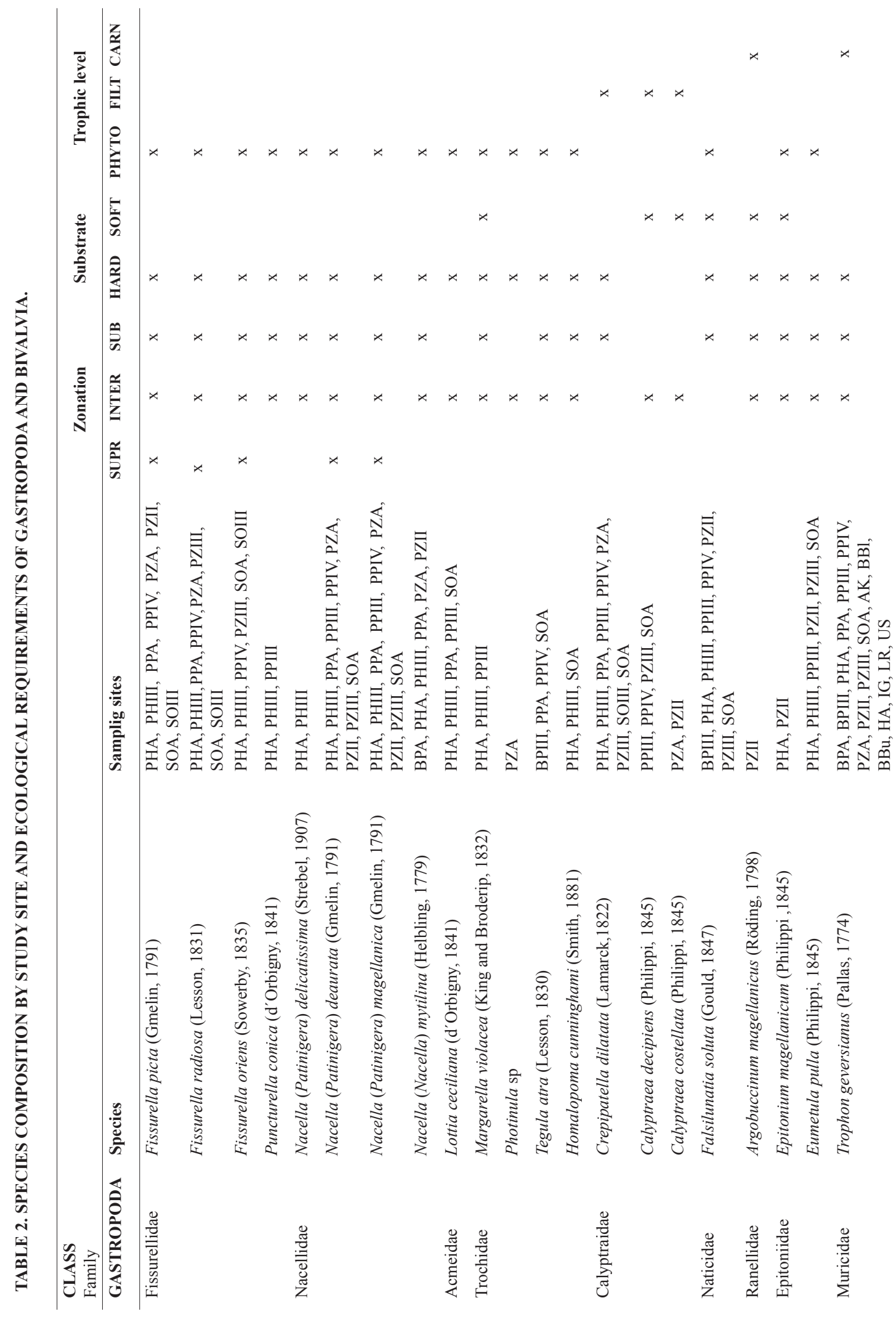




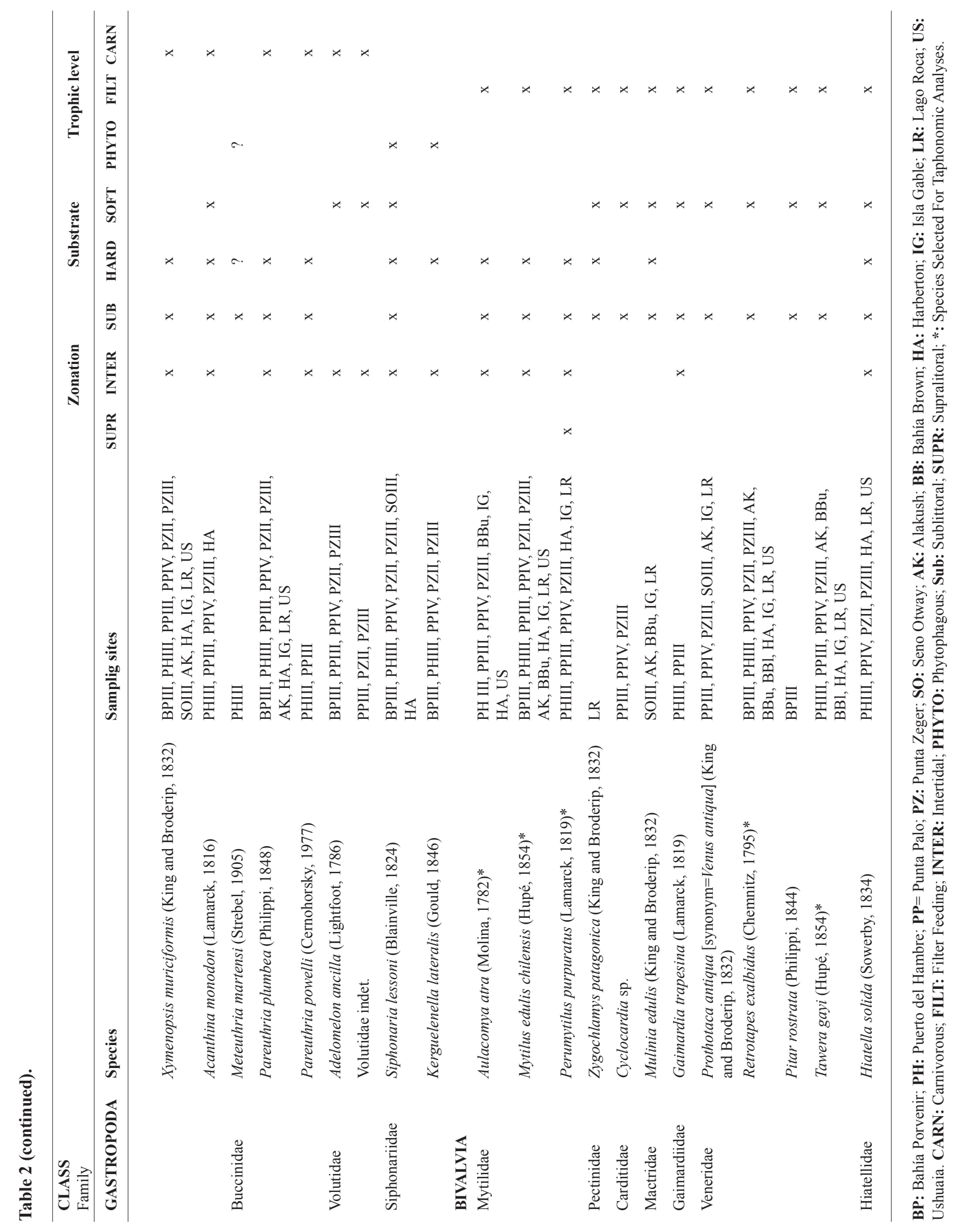



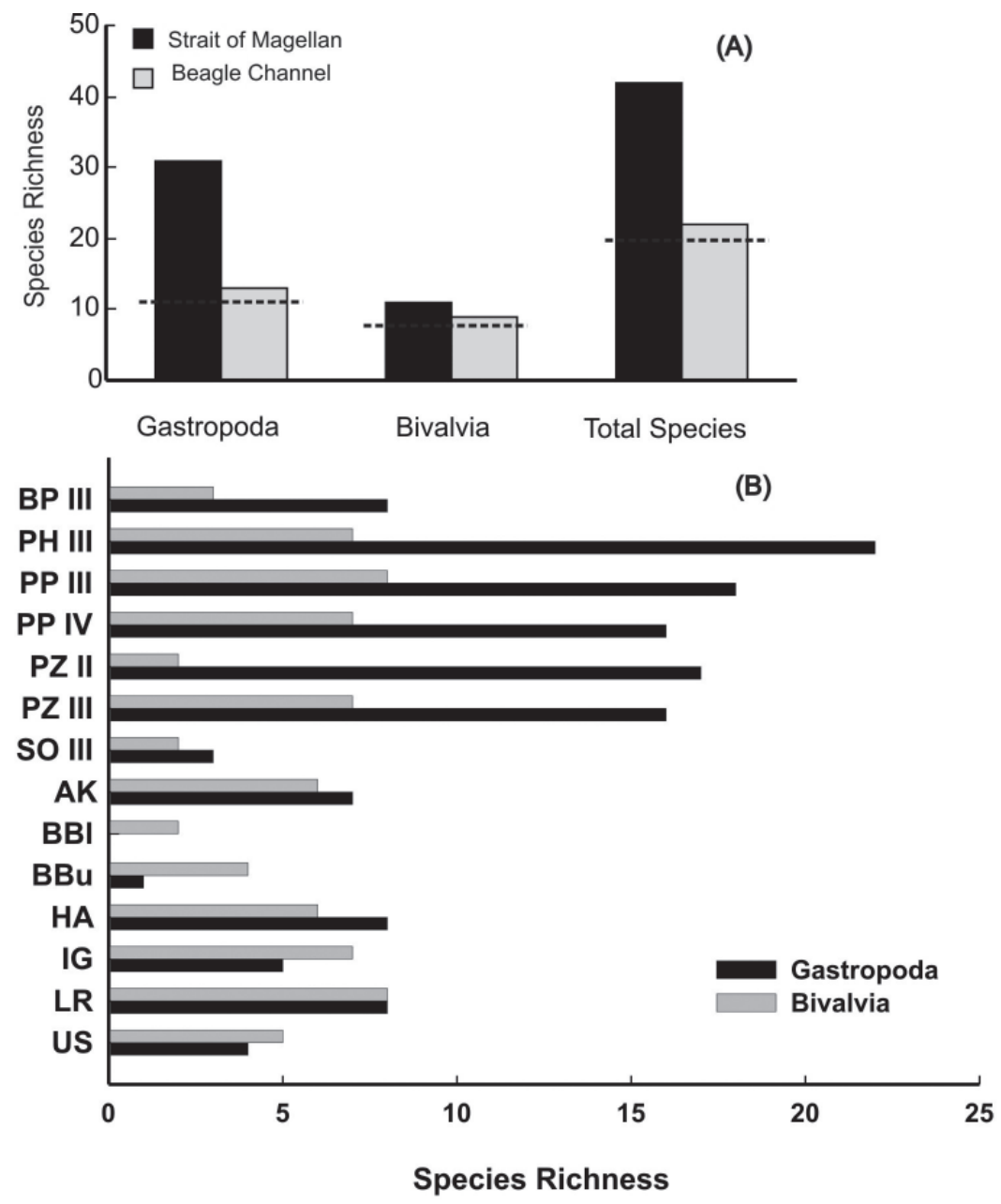

FIG. 2. Number of species collected in the Strait of Magellan and the Beagle Channel. A. Comparison between the Strait of Magellan and the Beagle Channel. The dotted line indicates the number of species shared between both areas; B. Species richness by each marine terrace BP: Bahía Porvenir; PH: Puerto del Hambre; PP: Punta Palo; PZ: Punta Zeger; SO: Seno Otway; AK: Alakush; BB: Bahia Brown; HA: Harberton; IG: Isla Gable; LR: Lago Roca; US: Ushuaia.

All mytilids (A. atra, P. purpuratus and M. edulis chilensis) analyzed were disarticulated, with highly fragmented and abraded valves (Table 3). Most venerids (T. gayi and R. exalbidus) were disarticulated, with moderate fragmentation and abrasion; the exceptions are PZII, PZIII terraces and BP site, where a few articulated specimens were collected. These infaunal species show traces of bioerosion on the valve surface, such as borings attributed to gastropod predators like Naticidae and Muricidae.

Beagle Channel terraces. Marine terraces located in this channel contain mainly infaunal bivalves. Most of these species are disarticulated and there is a moderate degree of fragmentation and abrasion throughout the different locations. However, few articulated specimens of $T$. gayi collected on the $\mathrm{AK}, \mathrm{BB}$ and HA terraces exhibit good preservation, moderate fragmentation and moderate or no abrasion in the valves. Tawera gayi and R. exalbidus show different levels of bioerosion (high, moderate and scarce). Although there are differences in the type of valves (left/right) among sites, deposits of AK, HA, LR and US have at least one species with an equal number of right and left valves. In the LR, all species have the same number of opposite valves. In addition, the attributes of fragmentation, abrasion and biotic interaction indicate good preservation and minimal transport. 


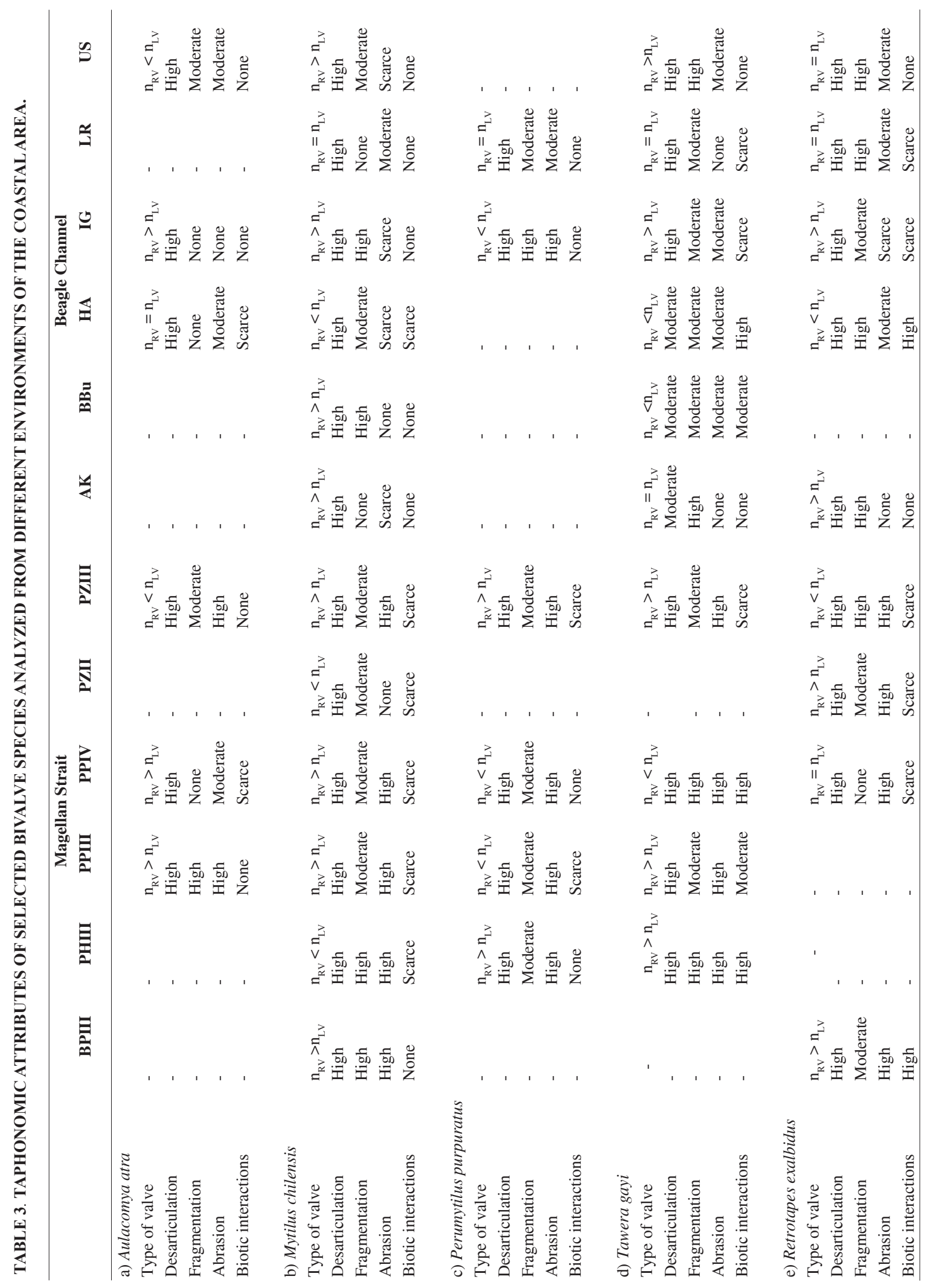




\section{Discussion}

\subsection{Taxa composition and paleoecology}

Of a total of 45 species cited in this work, 42 are in the deposits of the Strait of Magellan and only 22 in the Beagle Channel, which implied greater richness in the Strait of Magellan. However, previous studies of Gordillo (1999) and Gordillo et al. $(1992,2005)$ on deposits which also include other sites along the Beagle Channel indicate a total of 79 species for this channel, with Gastropoda (47 species) more diverse than Bivalvia (32 species). The species richness reported in these previous studies challenges a conclusion of greater diversity in the Strait of Magellan. Works by Porter et al. (1984) and Di Geronimo and Rosso (1996) only mention some Holocene paleontological mollusks and therefore provide a preliminary list for the Strait of Magellan deposits. In terms of relative abundance, the bivalves are the most representative, agreeing with the works mentioned above.

Differences in composition and paleoecology between the Strait of Magellan and the Beagle Channel are closely related to environmental factors such as substrate type, salinity and temperature (Fürsich and Flessa, 1987). Thus, changes in these factors may produce changes in the marine biota.

Global events, such as the climatic optimum, caused paleoenvironmental and geomorphologic changes in littoral zones that led to changes in assemblages of mollusks (Lutaenko, 1993; Camus, 2001). For instance, for the Argentinian coastlines, Aguirre et al. $(2005,2006)$ described the shift of warm water mollusks to higher latitudes on Bonaerensian coasts (south Atlantic) during the climatic optimum linked with a rise in the oceanic temperature and salinity. The effect of this period is still an open debate for southern Patagonia, although changes in sea level in Tierra del Fuego (Porter et al., 1984; Rabassa et al., 1986), as well as changes in moisture and temperature (Pendall et al., 2001; Kilian et al., 2007) have been documented. Results suggest that there are no changes in the species composition since 6,000 years $\mathrm{BP}$, which agrees with a previous work of Gordillo (1999) of deposits in the Beagle Channel. Likewise, all species analyzed in this work show a distribution that agrees with current references (Linse, 1999; Valdovinos, 1999; Osorio and Reid, 2004).
Although the diversity and stability of the communities have a close relationship to climatic variability (Walther et al., 2002), many taxa can tolerate small climate fluctuations or experience variations at the population level with morphometric and body size changes and relative abundance, thus showing an adaptation to different environments (Stahl, 1996; Roy et al., 2001). For instance, Gordillo (1992) found morphometric differences between modern and fossil specimens of Tawera gayi from the Beagle Channel. Likewise, size and shape of Hiatella solida shells are potentially related to many associated parameters including the primary influences of the substratum and temperature (Gordillo, 1995).

\subsection{Taphonomic aspects}

Environmental energy plays an important role in determining fossil preservation. For instance, fragile shells may remain intact in quiet waters for a long time prior to burial, and the damage they show is often of a nonmechanical nature (e.g., corrosion, bioerosion). High fragmentation and abrasion tends to occur in zones with high sedimentation rates indicative of high energy environments (Brett and Baird, 1986).

According to taphonomic analyses, two types of environment exist on the coasts of Tierra del Fuego, one of high energy in the Strait of Magellan terraces and the other of low to moderate energy in the Beagle Channel. In the Strait of Magellan, the epifauna shows high fragmentation and abrasion, thus implying that they were subject to long exposure on the sea bottom before burial, and was affected by biotic and abiotic factors. It is also possible that these taxa experienced shell transport in abrasive sediment due to currents in a high-energy setting such as a foreshore environment, and/or multiple reworking episodes (Speyer and Brett, 1991). In the Beagle Channel, fossil assemblages have moderate fragmentation and abrasion, indicating a low to moderate energy environment with dominance of soft bottoms as sand or small gravel, especially in the LR where the preservation suggests minimal transport and/or a minor influence of postmortem processes on the valves.

Despite the type of environment and external factors such as temperature, salinity and substrate, it is necessary to consider intrinsic factors such as 
biology, mode of life and mineralogy of the studied organisms to describe and interpret the processes that affect fossilization and the postmortem process (Lazo, 2004; Zuschin and Stanton, 2001). Epifaunal elements are thicker or have structures as byssus that give resistance and stability to organisms in conditions of high energy, but the long exposure to waves produced more fragmentation and abrasion of the shells, which creates a disadvantage in the preservation (e.g., Mytilus) (Zuschin and Stanton, 2001). Alternatively, the infaunal species support the results of other taphonomic works that describe the advantages of using infaunal bivalves, because they have a fast burial rate and the preservation is better than epifaunal organisms (Aguirre and Farinati, 1999; Nielsen and Funder, 2003). In this work, venerids show a good preservation in both zones of Tierra del Fuego and although abrasion and fragmentation in the deposits is moderate, this can be attributed to high bioerosion of their valves caused mainly by boring gastropods and/or encrusting elements on the surface of the shell (Zuschin and Stanton, 2001). In this regard, results show a relationship between the bioerosion level and the fragmentation in the deposits of the Strait of Magellan, i.e., deposits with high bioerosion also show high fragmentation. Nonetheless, in Alakush and Ushuaia (Beagle Channel) this relationship does not exist and the high fragmentation of venerids could be associated to different postmortem processes.

Other relevant factors related to preservation are the distribution of trophic and life habit groups. According to Gordillo and Aitken (2000), and to this study in the Strait of Magellan and Beagle Channel, the infaunal suspension feeders (bivalves) exhibit a high preservation potential, while carnivores and infaunal deposit feeders are a minor proportion of the Quaternary marine fossil records.

\section{Conclusions}

All fossil species collected in both zones correspond to mollusks occurring on modern beaches, which suggest that postglacial climatic changes were not enough to produce variations in the composition of the benthic communities or the environmental conditions since at least 6,000 yr BP in Tierra del Fuego. The qualitative differences between the faunistic elements of both regions, however, could be the result of different types of habitat. The local ecological variations are caused by the occurrence of two substrate types that exist in the region: epifaunal elements associated to hard or rocky bottoms (Strait of Magellan) and infaunal elements associated to sandy bottoms (Beagle Channel).

The taphonomic attributes of five bivalve species, well represented in the Holocene littoral deposits of Tierra del Fuego, are useful indicators of paleoenvironmental conditions. In particular, venerids show a higher preservation potential than mytilids, and their infaunal life cycle and their fast burial rate makes them more reliable to use in further taphonomic analyses.

Integration of taxonomic, ecologic and taphonomic analyses do not show any significant change, either in the molluscan composition or in the energy conditions of both areas since 6,000 years BP. Future research needs to consider stable isotopes $\left(\delta^{13} \mathrm{C}\right.$ y $\left.\delta^{18} \mathrm{O}\right)$ and morphometric analyses of the valves to evaluate changes in paleotemperature and other paleoenvironmental conditions during the Holocene, and their potential effects at the species level.

\section{Acknowledgments}

We are grateful to K. Linse (British Antarctic Survey), C. Valdovinos (Universidad de Concepción) and S. Nielsen (GeoForschungsZentrum Potsdam) for their valuable reviews of the manuscript. This work was partly supported by CONICET grant PIP 6323/05, Fundación CEQUA and Unidad de Sistemas Acuáticos Centro EULA, Universidad de Concepción.

\section{References}

Aguirre, M.L.; Farinati, E. 1999. Taphonomic processes affecting late Quaternary molluscs along the coastal area of Buenos Aires Province (Argentina, Southwestern Atlantic). Palaeogeography, Palaeoclimatology, Palaeoecology 149: 283-304.

Aguirre, M.L.; Negro Sirch, Y; Richiano, S. 2005. Late Quaternary molluscan assemblages from the coastal area of Bahía Bustamante (Patagonia, Argentina): Paleoecology and paleoenvironments. Journal of South American Earth Sciences 20: 13-32.

Aguirre, M.L.; Richiano, S.; Negro Sirch, Y. 2006. Palaeoenvironments and palaeoclimates of the Quaternary molluscan faunas from the coastal area of Bahía VeraCamarones (Chubut, Patagonia). Palaeogeography, Palaeoclimatology, Palaeoecology 229: 251-286

Andradre, S. 1991. Geomorfología costera y antecedentes oceanográficos físicos de la región de Magallanes, Chile $\left(48^{\circ}-56^{\circ} \mathrm{S}\right)$. Anales del Instituto de la Patagonia, 
Serie Ciencias Naturales, Chile 20 (1): 135-151.

Brambati, A.; De Muro, S.; Di Grande, A. 1998. Marine transition Holocene terraces in the Eastern area of the Straits of Magellan, Chile. Bollettino Di Geofisica Teorica ed Applicata 39: 47-76.

Brandt, D.S. 1989. Taphonomic grades as a classification for fossiliferous assemblages and implications for paleoecology. Palaios 4: 303-309.

Brett, C.E.; Baird, G.C. 1986. Comparative taphonomy: a key to paleoenvironmental interpretation based on fossil preservation. Palaios 1: 207-227.

Camus, P. 2001. Biogeografía marina de Chile continental. Revista Chilena de Historia Natural 74: 587-617.

Castellanos, Z.A.; Landoni, N. 1988. Catálogo descriptivo de la malacofauna marina magallánica 2. Archigastropoda: Scissurellidae, Fissurellidae, Patellidae, Acmaeidae y Lepetidae. Comisión de Investigaciones Científicas de la Provincia de Buenos Aires: $40 \mathrm{p}$.

Castellanos, Z.A.; Landoni, N. 1993. Catálogo descriptivo de la malacofauna marina magallánica 9. Muricidae y Thaisidae. Comisión de Investigaciones Científicas de la Provincia de Buenos Aires: 26 p.

Di Geronimo, S.I.; Rosso, A. 1996. Variations of palaeocommunities along gradients during the Quaternary. Berichte zur Polarforschung 190: 80-82.

Dillwyn, L.W. 1817. A descriptive catalogue of recent shells, arranged according to the Linnean method; with particular attention to the synonymy. John and Arthur Arch: 463 p. London.

Farinati, E.; Spagnuolo, J.; Aliotta, S. 2006. Bioerosión en micromoluscos holocenos del estuario de Bahía Blanca, Argentina. Ameghiniana 43 (1): 45-54.

Figuerero, M.J.; Mengoni, G.L. 1986. Excavaciones arqueológicas en la Isla El Salmón, Parque Nacional de Tierra del Fuego. Informes de Investigación 4: 1-195.

Fürsich, F.T.; Flessa, K.W. 1987. Taphonomy of tidal flat molluscs in the northern Gulf of California: Palaeoenvironmental analyses despite the perils of preservation. Palaios 2 (6): 543-559.

Gordillo, S. 1990. Malacofauna de los niveles marinos holocenos de la Península Ushuaia y alrededores (Canal Beagle, Argentina). In Reunión de campo de Geología del Cuaternario, No. 3, Resúmenes: 24-25. Bahía Blanca, Argentina.

Gordillo, S. 1991. Paleoecología de moluscos marinos del Holoceno Medio en Isla Gable, Canal Beagle (Tierra del Fuego, Argentina). Ameghiniana 28 (1-2): 127-133.

Gordillo, S. 1992. Tafonomía y paleoecología de moluscos bivalvos del Holoceno del Canal Beagle, Tierra del Fuego. Tesis doctoral, Universidad Nacional de Córdoba, Facultad de Ciencias Exactas, Físicas y Naturales: 286 p.

Gordillo, S. 1995. Recent and living Hiatella solida (Sowerby, 1834) (Mollusca: Bivalvia) from the Beagle Channel, Southernmost South America. Quaternary of South America and Antarctica Peninsula
9: $189-210$.

Gordillo, S. 1999. Holocene molluscan assemblages in the Magellan region. Scientia Marina 63 (Supl. 1): 15-22.

Gordillo, S.; Aitken, A. 2000. Palaeoenvironmental interpretation of Late Quaternary marine molluscan assemblages, Canadian Arctic archipelago. Géographie physique et Quaternaire 54: 301-315.

Gordillo, S.; Bujalesky, G.; Pirazzoli, P.; Rabassa, J.; Saliege, J.F. 1992. Holocene raised beaches along the northern coast of the Beagle Channel, Tierra del Fuego, Argentina. Palaeogeography, Palaeoclimatology, Palaeoecology 99: 41-54.

Gordillo, S.; Coronato, A.; Rabassa, J. 2005. Quaternary molluscan faunas from the island of Tierra del Fuego after the Last Glacial Maximum. Scientia Marina 69 (2): 337-348.

Gordillo, S.; Rabassa, J.; Coronato,A. 2008. Paleoecology and paleobiogeographic patterns of Mid-Holocene mollusks from the Beagle Channel (southern Tierra del Fuego, Argentina). Revista Geológica de Chile 35 (2): 1-13.

Hupe, L. 1854. Moluscos. In Gay: Historia física y política de Chile. Zoología. 8: 1-500.

Kilian, R.; Schneider, C.; Koch, J.; Fesq-Martin, M.; Biester, H.; Casassa, G.; Arévalo, M.; Wendt, G.; Baeza, O.; Behrmann, J. 2007. Palaeoecological constraints on late Glacial and Holocene ice retreat in the Southern Andes $\left(53^{\circ} \mathrm{S}\right)$. Global and Planetary Change 59: 49-66.

Lamarck, J.B. 1819. Histoire naturelle des animaux sans vertebres. Verguero, Deterville \& chez l'e auteur: 1343. Paris. 1-343. Paris.

Lazo, D.G. 2004. Bivalve taphonomy: testing the effect of life habits on the shell condition of the littleneck clam Protothaca (Protothaca) staminea (Mollusca: Bivalvia). Palaios 19: 451-459.

Linse, K. 1999. Mollusca of the Magellan region. A cheklist of the species and their distribution. Scientia Marina 63 (1): 399-407.

Lutaenko, K.A. 1993. Climatic optimum during the Holocene and the distribution of warm-water mollusk in the Sea of Japan. Palaeogeography, Palaeoclimatology, Palaeoecology 102: 273-281.

Molina, J.I. 1782. Saggio sulla storia naturale del Chili. Bologna: 1-367.

Nielsen, J.K.; Funder, S. 2003. Taphonomy of Eemian marine molluscs and acorn barnacles from eastern Arkhangelsk region, northern Russia. Palaeogeography, Palaeoclimatology, Palaeoecology 191: 139-168.

Osorio, C.; Reid, D. 2004. Moluscos marinos intermareales y submareales entre la Boca del Guafo y el Estero Elefantes, sur de Chile. Investigaciones Marinas 32 (2): 71-89.

Parsons, K.M.; Brett, C.E. 1991. Taphonomic processes and biases in modern marine environments: an actualistic perspective on fossil assemblage preservation. In 
The processes of fossilization (Donovan, S.K; editor) Belhaven Press: 22-65. London.

Pendall,E.; Vera, M.;White, J.W.C.; Dreier, M. 2001. Multiproxy record of late Pleistocene-Holocene climate and vegetation changes from a peat bog in Patagonia. Quaternary Research 55: 168-178.

Porter, S.; Heusser, C.J.; Stuiver, C. 1984. Holocene sea-level change along the Strait of Magellan and Beagle Channel, southernmost America. Quaternary Research 22: 59-67.

Porter, S.; Clapperton, C.M.; Sugden, D.E. 1992. Chronology and dynamics of deglaciation along and near the Strait of Magellan, southernmost South America. Sveriges Geologiska Undersökning 81: 233-239.

Rabassa, J.; Heusser, C.J.; Stuckenrath, R. 1986. New data on Holocene sea transgression in the Beagle Channel: Tierra del Fuego, Argentina. Quaternary of South America and Antarctic Península 4: 291-309.

Rabassa, J.; Coronato, A.; Bujalesky, G.; Salemme, M.; Roig, C.; Meglioli, M.; Heusser, C.; Gordillo, S.; Roig, F.; Borromei, A.; Quattrocchio, M. 2000. Quaternary of Tierra del Fuego, southernmost South America: an updated review. Quaternary International 68-71: 217-240

Reid, D.; Osorio, C. 2000. The shallow-water marine mollusca of the Estero Elefantes and Laguna San Rafael southern Chile. Bulletin Natural History Museum London (Zool.) 66: 109-146.

Manuscript received: November 11, 2007; accepted: October 17, 2008.
Roy, K.; Jablonski, D.; Valentine, J.W. 2001. Climate change, species range limits and body size in marine bivalves. Ecology Letters 4: 366-370.

Soot-Ryen, T. 1959. Pelecypoda. Report of the Lund University Chile Expedition 1948-1949. 35. Lunds Universitets Årsskrift. N.F. Avd. 2, 55 (6): 1-86.

Speyer, S.E.; Brett, C.E. 1991. Taphofacies controls background and episodic processes in fossil assemblage preservation. In Taphonomy: Releasing data locked in the fossil record, Topics in Geobiology 9 (Allison, P.A.; Briggs, D.E.; editors). Plenum Press: 501-545. New York.

Stahl, P.W. 1996. The recovery and interpretation of microvertebrate bone assemblages from archaeological contexts. Journal of Archaeological Method and Theory 3: 31-75.

Valdovinos, C. 1999. Biodiversidad de moluscos chilenos: Base de datos taxonómica y distribución. Gayana 63 (2): 111-164.

Walther, G.R.; Post, E.; Convey, P. ; Menzel A.; Parmesan, C.; Trevor, J.C.; Fromentin, J.M.; Ove H.G.; Bairlein, F. 2002. Ecological responses to recent climate change. Nature 416: 389-396.

Zuschin, M.; Stanton, R.J. 2001. Paleocommunity reconstruction from shell beds: a case study from the Main Glauconite Bed, Eocene, Texas. Palaios 17: 602-614. 